\title{
Environmental and Sustainable Development in Islamic Perspective
}

\author{
R. Sabrina \\ Universitas Muhammadiyah Sumatera Utara, Indonesia \\ r.sabrina@umsu.ac.id
}

\begin{abstract}
The development and preservation of the environment is a delamatic problem, as if there is some kind of complication between the objectives of development and the objectives of environmental preservation. This is because often factors (environmental kelastarian) are ignored / ignored in order to put forward the issue of national development which has more tangible benefits for the community. In order to overcome this problem, a sustainable and environmentally sound development agenda is needed, namely efforts to harmonize economic, social and environmental development. In economic, social and environmental development, Muslims have a strategic role because in Islam it has been regulated in the Quran, in Q. S 16:97, QS 2: 29, QS 6: 95, Q. S 6: 95, QS 10: 6, QS 16,66,67,68 and Q; 27.28. In the use of natural resources, we must pay attention to ecological elements, care for nature and not cause damage to the earth. This is in line with the concept of sustainable development. Muslims must participate in spreading environmental values and practice them through various professions or positions that are carried by Islamic teachings. Meanwhile, to face global challenges, Muslims must learn science and technology, stop excessive environmental exploitation and the industrial world plays a role in overcoming environmental damage.
\end{abstract}

Keywords

Islam environmental; sustainable development

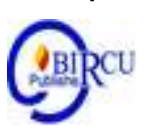

\section{Introduction}

The economic development paradigm recommended for accelerating economic growth in developing countries by western literature theory is growth (Imam Kabul 2006: 7). In this theory it is recommended that developing countries make use of natural resources, technology and capital by industrializing. Not a few developing countries believe in this theory and implement it in an inappropriate way. In the last thirty years development planners have become increasingly aware of the importance of the implications of various environmental problems for the success of development efforts. (Nasrudin, Agustina, Akrim, Ahmar, \& Rahim, 2018). We know that accelerated development that is not environmentally friendly will increase the poverty gap and will directly accelerate environmental degradation. Degredation and environmental damage can reduce development itself, natural resources are destroyed, damaged or polluted (Emil Salim 20010: 25).

Sustainable development is not only related to environmental aspects, but also economic and social development, which is known as the living triangle. It is impossible for the environment to be properly preserved if the social conditions of the community are bad. Therefore, in order to conserve the environment in a sustainable manner, sustainable economic and social development is also needed (Sulasmi, 2020b). 


\section{Review of Literatures}

\subsection{Sustainable Development}

National Development is a series of continuous development efforts covering all the lives of the people, nation and state to carry out the task of realizing the national goals as stipulated in the Preamble to the 1945 Constitution. In implementing national development it is necessary to pay attention to the three pillars of sustainable development in a balanced manner, this is in accordance with The results of the United Nations Conference on the Environment held in Stockholm in 1972 (United Nations Conference on the Human Environment 1972) and an Environmental Declaration of the Earth Summit in Rio de Janeiro in 1992 (United Nation 1992) which agreed on the principles in making development decisions must pay attention to the dimensions environment and people as well as the Sustainable Development Summit in Johannesburg in 2002 (World Summit on Sustainable Development 2002) which discusses and addresses the deterioration of environmental quality.

Environmental problems in Indonesia are mainly rooted in underdevelopment (Daud Silalahi 2001: 18) considering that a reliable contribution in contributing to economic growth and sources of foreign exchange as well as development capital is from natural resources, it can be said that natural resources have an important role in the Indonesian economy. Past, present and future, so in its application, it must pay attention to what has been agreed by the international community. Adi in Saleh (2019) argues that community empowerment can also be seen as a program as well as as a process. Empowerment is called a program when viewed from the stages. Empowerment as a process when empowerment is to go on all the time. However, in addition to natural resources making a major contribution to development (Journal of Environmental Economics 2009: 1), on the other hand the sustainability of their availability is often ignored and so are the rules that must be obeyed as a basis for implementing the management of a business and / or activities to support the development of a lacking economic sector. attention, so that there is a tendency for a decrease in the carrying capacity of the environment and the depletion of available natural resources and a decrease in the quality of the environment. Management of natural resources and the environment that is not carried out in accordance with their carrying capacity can lead to a food crisis, water crisis, energy crisis and the environment. (M. Akrim \& Harfiani, 2019).

In the implementation of development in the Regional Autonomy era, environmental management still refers to Law No. 32 of 2009 concerning Protection and Management of the Environment and also Law No. 32 of 2004 concerning Regional Government and Law No. 33 of 2004 concerning Financial Balance. Central and Regional. In exercising its authority, it is regulated by Government Regulation No. 38 of 2007 concerning Government Authority and Provincial and Regency / City Authority as Autonomous Regions.

In line with the pace of national development being implemented, environmental problems that are currently being faced are environmental damage, among others, around mining areas that have the potential to damage the landscape and overlapping land uses for mining in protected forests (Sudarmaji 2008: 1). Environmental pollution cases also tend to increase both water and air pollution. The progress of transportation and industrialization that is not accompanied by the application of clean technology has a negative impact, especially on the urban environment. Urban rivers are polluted by industrial and household waste. Soil conditions are increasingly polluted by chemicals from solid waste, fertilizers and pesticides..

This pollution problem is caused by the low awareness of business actors or public awareness to live clean and healthy with good environmental quality. Environmental 
problems are not getting lighter but they will get heavier, especially considering that natural resources are used to carry out development aimed at fulfilling and improving community welfare. (Akrim, Zainal, \& Munawir, 2016). Under these conditions, the quality of sustainable natural resource and environmental management needs to be improved with the support of fair and firm environmental law enforcement, quality human resources, expanding the application of environmental ethics and increasingly stable socio-cultural assimilation. There needs to be a push towards a change in perspective on the environment with environmental ethics insight through internalization into production and consumption activities/processes, and instilling environmental values and ethics in everyday life, including social learning processes and formal education at all levels. (Nasrudin et al., 2018).

Sustainable development implies guaranteeing the quality of human life and does not exceed the ability of ecosystems to support it. Thus the notion of sustainable development is development to meet current needs without reducing the ability of future generations to meet their needs (Muhammad Soerjani, Arief Yuwono 2007: 67). Sudarmaji (2008: 2) argues that this concept contains two elements:

- The first is needs, especially the basic needs of the group disadvantaged communities, which desperately need high priority from all countries.

- The second is limitations. Mastery of technology and social organization must pay attention to the limitations of the ability of the environment to meet human needs at present and in the future.

Thus the concept of sustainable development arises and develops due to the emergence of an awareness that economic and social development cannot be separated from environmental conditions.

\subsection{Islam and Living Environment}

The Islamic view is very positive towards the environment and very preventive, even the Islamic concept of the environment has existed since the Qur'an was revealed. This can be seen from the contribution of the Quran to the following environment: He is Allah who created you from the earth element and ordered you to prosper and manage the environment (Q.S 17: 61). The message of this verse, according to Ibn Kathir, is to carry out development and manage the earth, meaning that prosperity on this earth occurs when humans make good and proper use of the environment in an ecological perspective. The concept of the Quran as such is derived from environmental verses such as whoever does good, male or female, as long as he believes he will undoubtedly get a quality life (Q. S 16.97). The benchmarks for quality and achievement are based on the final product of the development work carried out (Yulianto, 2002).

The Quran regulates quite completely the environment as seen from various aspects of human life. The main goal for the welfare of mankind in the world and the hereafter. It is he who has made for all of you who are on earth (Q S.2: 29) this shows that humans are given authority, the basis of human authority is ordered to pay attention to natural phenomena that are elements in ecosystems such as water phenomena (Q, S 6: 95) night and day (Q, S 10:6) grow grain of plants (Q, S 6: 95), livestock (Q, S: 16,66,67,68) and others.

Based on the Islamic concept, it is very clear that all people on earth in utilizing natural resources must be for their prosperity and be followed by maintenance activities and to prevent damage to existing natural resources. The purpose of utilizing natural resources is to develop a balance between efforts to improve the welfare of life and the preservation of the ecosystem so that it is sustainably beneficial for all humans. The Quran confirms that in another verse Allah SWT reminds you, and do not do damage on the earth, because Allah does not like those who do damage (QS 28:77). 
Whether we realize it or not, the current development pattern has violated Islamic religious principles regarding the use of natural resources. This can be seen from the excessive exploitation of natural resources such as: deforestation, mining exploitation, industrialization which is always pursuing the highest profit. The impact that is caused is as shown by scientists from the results of their research that the planet earth is threatened by climate change, and habitat loss and unlimited exploitation by humans and the increasing extinction of species. Various types of diseases have sprung up and human life will be threatened, if the environmental damage is not immediately stopped or immediately repaired (A. Akrim, 2018; Mr Akrim, 2018).

Humans are the most glorious creatures of Allah, who were created perfect, endowed with a mind and mind that can distinguish between rights and what is false. Allah bequeathed the earth to humans to become caliphs who bring peace and prosperity (Sulasmi, 2020a).

Humans are responsible for what they do, because humans can do things freely (fa alhaamha fujuuraha wa taqwaaha). Humans are also equipped with the ability to think (afala ta'qiluun, afala tatafakkarun and so on). Whatever actions humans choose, the damage or improvement of nature is subjected by Allah to humans (QS 36:72), including things that have never been imagined by humans before (QS 11:61) with the "equipment" prepared by Him in the form of "packages of reason. And, conscience". The fate of the earth and life here are in human hands. If humans are wise, prosperity will spread on the earth, but if not, destruction is just around the corner.

H.Mal An Abdullah 2008: 6) explains that the factors that encourage humans to destroy and pollute the environment are: first, the application of the law is too weak and unbalanced. The number of perpetrators of the destruction was carried out by unscrupulous people. Law enforcers cannot act or impose sanctions or sentences that are too light for perpetrators of environmental destruction; second, human greed. In fact, environmental destruction is mostly carried out by people who are capable / sufficient and who have influential positions in government. Third, because of poverty and poverty. Indulgence and poverty sometimes make people act beyond their common sense, including destruction and pollution of the environment (Sunhaji, 2014). Martinelli (2019) stated that a serious problem facing the world today is the distribution of economic wealth fairly and equally. The unfair economic distribution causes the maintenance of poverty throughout the ages.

As a sacred teaching (rahmatan lil 'alamin), religion invites humans to become righteous and mushlih creatures. According to the Quraish Shihab, being righteous is maintaining the value of something so that its good condition does not change, as it is, continues to function and be beneficial. H. Mal An Abdullah (Et.al 2008: 7) argues that a mushlih is to find missing or reduced values or functions, then fix the decreasing values or functions so that they can be united again, especially if you can add values. which is even better (A. Akrim \& Sulasmi, 2020; M. Akrim \& Harfiani, 2019).

Apart from that, of course there are messages that are more specific, for example teachings about cleanliness of the body and the environment, as well as cleanliness of the liver. The Prophet Muhammad prohibited the Companions from killing animals, which, if you think about it, is useful for maintaining the balance of the ecosystem (Tobroni, 2015).

Thus, Islam essentially guides people to develop behavior to support the balance of ecosystems and environmental sustainability, which are placed within the framework of the Caliphate's task of building prosperity on earth. The glory of human life requires balance and preservation of resources in all fields, both material and related to the soul, reason, emotions, passions and feelings of humans. Islam guides people to maintain this balance and sustainability, which in the language of religion is often called al-tawasuth or al-i'tidal. 
According to fazlun khalid (Director of the Islamic Foundation on Ecology and Environmental Science, IFEES 2005), natural resources are a great gift that must be preserved and can be utilized by current and future generations, where the Muslim world has a positive tradition of contributing. However, in reality Muslims themselves have not been able to take smart steps to preserve this environment. As described by Richard Foltz (2005), "the environmental crisis in its local and global forms has hit the world's poor most severely, most of whom are Muslim. The fact is that the majority of Muslims are in developing countries, and it is in these countries that environmental problems are being treated more and more as a result.

When we reopen the Quran and various other holy books, it is clear that natural disasters and environmental crises are the result of human activity. Environmental damage has long been pointed out in the Quran. In a verse Allah says, "It has appeared that the damage on land and in the sea has been caused by the actions of human hands, so that Allah will feel for them a part of their actions, so that they will return to the right path" (Q S. . This verse explicitly states that the damage on earth is caused by human hands. The disasters that come and go along with the increasingly severe natural destruction are not anyone's fault, not natural phenomena, but the fault of humans themselves who are not wise in managing them (like what we see every day on television).

The occurrence of damage is the result of sins and violations committed by humans, resulting in a disturbance of balance on land and at sea (Ministry of Environment 2008: 7). On the other hand, this lack of balance results in torment to humans. The more damage to the environment, the greater the negative impact on humans, including the impact on innocent humans around them. The more numerous and varied human sins (including illegal logging, illegal mining, corruption, etc.), the more severe the environmental damage and natural disasters will be. If there is a disturbance in the harmony and balance of nature, then the damage will occur (small or large), it must have an impact on all parts of nature, including humans, both those who destroy or bless the damage. (Agussani, 2020; Agussani \& Bahri, 2019).

Al-Quran when discussing nature or talking about environmental issues, uses several terms, namely al-'alamin (all species or creatures) is mentioned 71 times, al-sama '(space and time) is mentioned 387 times (210 plurals and 177 singular), al-ardl (earth) is mentioned 463 times, and al-bi'ah (environment) is mentioned 15 times (Nabiel Fuad Almusawa 2005: 2).

The word al-bi'ah which means environment is found in QS 3: 21, Q S 7: 74, Q S 10: 93, Q S 12: 56, Q S 16: 41, and QS 29: 58. The use of the Quran in these verses connotes the environment of living space, especially for the human species. So, when talking about natural issues, what the Quran means is not only the environment of human life, but the nature of all species (creatures) both on earth and in space, even in outer space. (Muhaimin, 2004).

According to Islam (Al-Quran) nature is not just an object which means nothing but is used to meet human needs. Nature in the view of Islam (Al-Quran) is a sign (verse) of Allah's "being". Nature provides a way for humans to know His existence. Allah said, "And on the earth there are signs (of Allah's power) for those who believe," (QS 51: 20).

In the Quran, many are found when talking about nature followed by suggestions for thinking, understanding, remembering, being grateful, and doing meditation (Nabiel Fuad Almusawa 2005: 2) All of this will lead humans to something that is Absolute which created nature in harmony with the laws that govern it. Nature is the signs (verse) of Allah, in the sense that nature announces the existence of Allah as the creator of nature.

Nature is the manifestation of all the names and attributes of Allah. For example, plants reflect the Divine attributes of knowledge because plants "know" how to find food and light, fruits manifest God's gifts and gifts, and animals reflect the four divine attributes; life, 
knowledge, desire and power. Since nature is the locus of manifestation of all the divine names and attributes, destroying nature means destroying the "face" or sign (verse) of God on earth. Humans, especially Muslims, must treat them well because they are a ladder to contemplate the omnipotence of Allah. Reflections on the beauty and harmony of nature will lead Muslims to become devout people.

In the Quran, Allah states that nature was created to meet human needs. Allah said, "And He subjected to you what is in the heavens and what is on the earth all, (as a grace) from Him. Indeed, in this way there are signs (of Allah's power) for people who think, "(Surah 45: 13). This verse is the theological basis for the justification of the management and utilization of natural resources to meet human needs. Islam does not prohibit using nature, but there are rules for the game. Take advantage of nature in a good way (wisely) and humans are responsible for protecting nature and the environment and prohibiting damage to it (Abdillah Mujiyono 2001: 150).

Humans as khalifah (representative or substitute) of Allah, one of the obligations or duties is to make the earth prosperous. This shows that the sustainability and destruction of nature is in the hands of humans. In Islam (Al-Quran), the right to manage nature cannot be separated from the obligation to maintain its dances (the synergy of the two). Managing nature must be accompanied by efforts to preserve it. The number of verses of the Quran that discuss the prohibition of destroying the earth, indicates the obligation of Muslims to maintain the sustainability and beauty of the earth. Every destruction of the environment must be seen as self-destruction. Islamic moral guidance in managing nature is the prohibition of being greedy and wasting it (read; Q S 7: 31 and Q S 17: 27), as well as many explanations about this environment through the hadiths of the Prophet Muhammad.

Humans must accompany nature to praise Allah, among other things, to preserve nature and direct it to a better direction (islah), and not do damage to the earth (fasad fi al-ardl). Islam allows management of the earth and its use on the condition of preservation and sustainability, not to destroy natural habitats.

\section{Discussion}

\subsection{Sustainable Development Failed}

The call for the implementation of sustainable development has not produced much fruit because the world community has not caught the vision of sustainable development as a means to prevent environmental damage from occurring but rather as an obstacle to the implementation of natural resource utilization. The poverty of third world societies and capitalists also affects behavior and attitudes towards the environment, as stated by Nafis Sadik, Executive Director of the United Nation Population Fund, (1991) that all the degradation or damage to the world's environment that is happening today is the most people. rich and the second most poor people.

The failure of economic and environmental development in the world today is caused by a separate view between economics and religion. Economic development seems to be the main goal of human life which is marked by economic measures such as per capita income. The result is that all developing countries are massively risking their natural resources to be exploited in order to achieve the highest per capita income without neglecting the damage to existing natural resources. The concept of sustainable economic development is only a concept that is far from reality because economic development is more won and environmental development tends to be defeated.

There is a lot of evidence that shows that deforestation is for industrialization, massive mining, without being followed by replanting, industries that do not have waste processing, 
but there has never been a law that clearly states them guilty. However, they are still considered as the ones who contribute to the per capita income even though in the long term this behavior will lead to many natural disasters. The dryness of religious attitudes in economic development has contributed greatly to environmental damage today, doesn't Islam have regulated all human behavior in utilizing natural resources for the prosperity of society through the verses of the Qur'an as quoted above.

Economic development that only relies on growth without being followed by religious principles will in the long run only bring about a major disaster for mankind on this earth. (See cases of natural disasters that occurred today). So the failure of sustainable economic development is caused by the negligence of mankind not to make religion the main guide in economic development but only to pursue income growth alone. Seeing this phenomenon, Muslims must rise and become the pioneers of economic development based on religion in order to prevent environmental damage on this earth.

\subsection{The Role of Islamic People in the Management of the Environment}

In accordance with the motto as a religion that is rahmatan lil alamin (love for the universe; (QS 21: 107), it is only natural for Islam to become a pioneer in environmental management as a manifestation of compassion for the universe. Apart from prohibiting damage to the earth, Islam also has an obligation to maintain a shady, beautiful clean environment (Agus Sofyan 2010: 4) Because cleanliness is part of the life of the Islamic community as expressed by the prophet Muhammad SAW with his hadith which reads: "Cleanliness is a part of faith".

Islam invites humans to actively manage the environment, among others, by disposing of garbage in its place. This is in accordance with Islamic philosophy which generally prefers to prevent (preventive) bad actions or incidents rather than cure (curative) bad events or actions that occur. However, Islam also does not stand idle when there has been a bad incident or crime, such as stated in the religious law (syar'i) which regulates the punishment for breaking the rules.

Imam Kabul (2008: 2) argues that demographically, the number of Muslims is relatively large, which is around 1.5 billion and this number is expected to continue to increase, Muslims have great potential in saving the environment. If Muslims consistently implement the teachings of the Koran as stated above, environmental damage will be minimized. Indonesia has an economic characteristic that relies on natural resources with the largest number of Muslims. A large number of Muslims is a great asset to carry out sustainable economic development on condition that Muslims must understand and know Islamic concepts about the relationship between economic development and the environment and do so in real actions in daily life. If only there was a commitment from all Muslims in the world every year, each person planted a tree, then in this world there would be an addition of about one and a half billion new trees every year. The movement for six years will produce 9 billion new trees and will match the world's population. This step is very effective in preventing damage to the world's environment. Tree planting can be concentrated on critical land, vacant land in households or public facilities. We can cultivate productive tree species so that they can support the community's economy.

In terms of occupation and position, Muslims have varied occupations and positions. It is hoped that everyone will have a commitment to their position to always uphold environmental values as an effort to preserve the environment based on Islamic teachings. For example, if a leader who is Muslim is obliged to make an environmentally friendly economic development policy, a teacher is obliged to disseminate environmental-friendly 
economic development programs to his students, a lecturer must teach environmental functions in economic development.

In principle, every Muslim from all walks of life must play an active role in environmental management in accordance with their field of work or in accordance with their respective fields of expertise based on Islamic teachings.

There are several aspects that can be done by Islam in environmental management, including environmental education, Islamic mass media, and Islamic environmental law enforcement policies. (Agus Sofyan, 2010: 4)

\section{a. Environmental Education}

Environmental education which is taught in Islamic way is an important means for Muslims to know and be aware of their living environment properly and correctly so that they can play a conscious and active role in environmental management and development. As the majority of Indonesia's population, Muslims have a very big obligation and role in environmental management. It takes deep knowledge and awareness that Islam is very concerned about the environment and health. This requires the role of educators, scholars and community leaders to impart this knowledge and awareness to society. The awareness that the universe belongs to Allah SWT is a basic step in understanding the position of humans in this world. In several verses of the Alqur'an Allah SWT explains that Allah SWT created the universe and its contents with careful, balanced considerations, and each of His creations has benefits and functions (QS 6: 38, 16: 66 to 69; 25: 2, 54: 49, 80: 24 s / d 32).

Furthermore, Allah SWT also states that man is His unique creation and makes him a caliph on earth (QS 6: 165, QS 7: 69 and 129; QS 10: 14, QS 24: 55, QS 38: 26). In Islamic teachings, the caliph is more of a manager or manager on this earth, while Allah SWT is the absolute owner of the earth and everything in it. Allah SWT gave humans the right to take advantage of the earth and its contents, but Allah SWT also gave humans an obligation to protect the earth and its contents. This is in accordance with the United Nations Declaration on sustainable development, which contains instructions and information on the use and management of natural resources for development and the continuation of development itself. Sustainable development is development in all fields (for example, economic, social and political) which still takes into account the availability of adequate natural resources for future generations. This development pays close attention to the carrying capacity of the environment, so that it does not arbitrarily use up the available natural resources. This is in accordance with the advice of the Prophet Muhammad to live simply and not be wasting our assets and resources. Furthermore, sustainable development also takes into account the aspects of human resources as actors and the person in charge of this development. Improving the quality of human resources who are smart and wise is highly emphasized in Islam.

In rural communities who are mostly primordial, the role of ulama and community leaders in the success of environmental management programs is very large. Rural communities are generally passive and imitate the actions of their ulama or leader. For this reason, it is only natural for scholars, leaders, or prospective scholars and community leaders to equip themselves with adequate knowledge about environmental and health management. In urban communities who are generally more individualistic, Muslim intellectuals are expected to be good examples in protecting and managing the environment, because with the knowledge they have, they should be able to harmonize and integrate religious orders with their role as part of spreading love for the universe.Selanjutnya, Allah SWT juga menyatakan bahwa manusia adalah ciptaaanNya yang unik dan menjadikannya sebagai khalifah di bumi (Q S $6: 165$, Q S 7 : 69 dan 129; QS $10: 14$, QS 24 : 55, QS 38 : 26). 
In Islamic teachings, the caliph is more of a manager or manager on this earth while Allah SWT is the absolute owner of the earth and everything in it. Allah SWT gave humans the right to take advantage of the earth and its contents, but Allah SWT also gave humans an obligation to protect the earth and its contents. This is in accordance with the United Nations Declaration on sustainable development, which contains instructions and information on the use and management of natural resources for development and the continuation of development itself. Sustainable development is development in all fields (for example, economic, social and political) which still takes into account the availability of adequate natural resources for future generations. This development pays close attention to the carrying capacity of the environment, so that it does not arbitrarily use up the available natural resources. This is in accordance with the advice of the Prophet Muhammad to live simply and not be wasting our assets and resources. Furthermore, sustainable development also takes into account the aspects of human resources as actors and the person in charge of this development. Improving the quality of human resources who are smart and wise is highly emphasized in Islam.

In rural communities who are mostly primordial, the role of ulama and community leaders in the success of environmental management programs is very large. Rural communities are generally passive and imitate the actions of their ulama or leader. For this reason, it is only natural for scholars, leaders, or prospective scholars and community leaders to equip themselves with adequate knowledge about environmental and health management. In urban communities who are generally more individualistic, Muslim intellectuals are expected to be good examples in protecting and managing the environment, because with the knowledge they have, they should be able to harmonize and integrate religious orders with their role as part of spreading love for the universe.

\section{b. Islamic Mass Media}

The role of the Islamic mass media is no less important than education, even as a partner that is quite relevant to support environmental education. Islamic mass media must also be filled with environmental education, especially for children and the younger generation so that they are aware of the relationship between religion and the environment and the importance of this relationship for the welfare and health of humans and the environment. For adults, the mass media also needs to insert education about the health hazards caused by environmental damage and also knowledge about sustainable development which is in accordance with the breath of Islam.

\section{c. Islamic Environmental Policy and Law Enforcement}

Islam emphasizes that every individual will be held accountable on the day of retribution for all their behavior on earth, including how the individual acts towards nature, the environment, and other living things. Islam in no way prohibits the use of the environment for human welfare, but Islam requires that in such use, excessive use must be avoided so that it can cause environmental damage and endanger other living things including humans themselves. Islam advises on sustainable utilization which will ultimately be able to provide equitable and sustainable welfare for humans and other living things.

\subsection{Challenges for the Future of Islamic People}

Imam Kabul (2008: 2) states that to realize the role of Muslims in sustainable development there are several challenges that must be faced, (1) global economic challenges that are very pro-capital and technology, (2) the emergence of multi-international companies based on natural resources often deceive people in developing countries, especially Muslims 
whose lives are very dependent on natural resources. The onslaught of the global economy must be watched out for as a trade policy for developed countries to expand the market for their products. The result is the industrial countries ambitious in accelerating economic growth, which often violates ethics by pressuring developing countries to always protect the environment, even though they are the ones who enjoy the most of the world's economic growth. They should also be responsible for the damage to the environment in the world today.

\section{Conclusion}

As a religion that is rahmatan lil alamin, Islam places the use and management of the environment as an integral part of the worship process carried out by its adherents. The obligation of every Muslim to maintain a good environment is contained in the Alquran and is also given an example in several prophetic hadiths, including rewards or punishments for not heeding these obligations. Continuous efforts still have to be made to awaken the ummah so that good and integrated environmental management becomes a part of life. In addition, being aware of the severe punishment that Allah SWT will give to people who do damage will keep them away from that destructive act.

The Islamic ummah must be able to demonstrate that they have built the concept of sustainable economic development first than the UN concept of sustainable development which was born when signs of global environmental damage began to be felt.

By applying the Islamic concept, an environmentally sound development will be created for the present and future generations. Amen.

\section{References}

Abdillah Mujiyono, Agama Ramah Lingkungan Perspektif Al-Qur'an,Paramadina, Jakarta, 2001.

A. Akrim. (2018). Ilmu Pendidikan dalam Persfektif Islam. In Bildung. Yogjakarta: Bildung. Agussani. (2020). Indonesian Women Entrepreneurs : A Review Literature. 7(4).

Agussani, \& Bahri, S. (2019). A qualitative study on the role of family and social circles among women entrepreneurs in Indonesia. International Journal of Innovation, Creativity and Change, 8(2), 222-239.

Akrim, A., \& Sulasmi, E. (2020). Student perception of cyberbullying in social media. Talent Development and Excellence, 12(1), 322-333.

Akrim, M., \& Harfiani, R. (2019). Daily learning flow of inclusive education for early childhood. Utopia y Praxis Latinoamericana, 24(Extra6), 132-141.

Akrim, Mr. (2018). Media Learning in Digital Era. 231(Amca), 458-460. https://doi.org/10.2991/amca-18.2018.127

Akrim, Zainal, \& Munawir. (2016). M-97 Developing Model and Textbook Integrated to Spiritual and Social Competence of Math Subject for Grade VII in State Junior High School of Medan. International Conference on Mathematics, 2016(Icmse).

Harun Yahya, Islam Agama Yang Berkembang Paling Pesat di Eropa, http://www.google.com

Imam Kabul, Hukum Ekologi Indonesia, VisiPress, Surabaya, 2006

Iwan J Azis dkk, Pembangunan Berkelanjutan Peran dan Kontribusi Emil Salim, Kepustakaan Populer Gramedia, Jakarta, 2010

Komisi Pembangunan dan Lingkungan Perserikatan Bangsa-Bangsa, Hari Depan Kita Bersama, Penerbit PT Gramedia Jakarta, 1987. 
Kementerian Lingkungan Hidup, Jurnal Ekenomi Lingkungan,Edisin13 2009.

Kementerian Lingkungan Hidup RI, Bunga Rampai Islam dan Lingkungan Hidup, 2008,

Martinelli, I., Harahap, A., and Zainuddin. (2019). Community Economic Development Prospect Based on Wakaf Funds. Budapest International Research and Critics InstituteJournal (BIRCI-Journal), P. 409-423.

M. Daud Silalahi, Hukum Lingkungan Dalam Sistem Penegakan Hukum Lingkungan Indonesia, Alumni Bandung, 2001

Michael P. Todaro, Pembangunan Ekonomi Dunia Ketiga, Penerbit Erlangga, Jakarta,1998.

M.Soeryani, 2007, Lingkungan Hidup, Yayasan Institut Pendidikan dan Pengembangan Lingkungan, Jakarta

Muhaimin. (2004). Paradigma pendidikan Islam: Upaya mengefektifkan Pendidikan Agama Islam di sekolah. Bandung: Remaja Rosdakarya.

Nasrudin, N., Agustina, I., Akrim, A., Ahmar, A. S., \& Rahim, R. (2018). Multimedia educational game approach for psychological conditional. International Journal of Engineering and Technology(UAE), 7(2), 78-81.

Saleh, A., et al. (2019). Development of Banking CSR Model for Community Empowerment Slum Area in Medan City. Budapest International Research and Critics Institute-Journal (BIRCI-Journal), P. 39-50.

Sulasmi, E. (2020a). Konsep Pendidikan Humanis Dalam Pengelolaan Pendidikan Di Indonesia. 162. https://doi.org/10.1017/CBO9781107415324.004

Sulasmi, E. (2020b). The Development Strategy of Human Resources Management In Children's Social Welfare Institution ( LKSA ) ( Case Study in LKSA AL-Mubaraak Orphanage Bengkulu ). 562-569.

Sunhaji. (2014). Model pembelajaran integrtif Pendidikan Agama Islam dengan sains. Insania, 19(2).

Tobroni. (2015). Pendidikan Islam; Dari Dimensi Paradigma Teologis, Filosofis dan Spritualitas Hingga Dimensi Pragsis Normatif. Jakarta: Mitra Wacana Media.

Yulianto, E. (2002). Pendekatan Lingkungan pada Pembelajaran IPA. Jakarta: Pelangi Pendidikan.

Yusmin Alim, Lingkungan dan Kadar Iman Kita, http://www.google.com

Yusmin Alim, Lingkungan dan Aksioma Kerakusan Kita, http://www. google.com Kontribusi Al Quran pada Lingkungan Hidup, http://www google.com 